\title{
Assessment of a New Dam Site for Water Supply Potential in Bauchi Metropolis, Nigeria
}

\author{
O. B. E. Salau ${ }^{1}$, A. Salaudeen ${ }^{1 *}$, B. A. Gana ${ }^{2}$, I. Zubairu', S. I. Musa ${ }^{3}$ \\ ${ }^{1}$ Department of Civil Engineering, Abubakar Tafawa Balewa University, Bauchi, Nigeria. \\ ${ }^{2}$ Department of Environmental Management Technology, Abubakar Tafawa Balewa University, Bauchi, \\ Nigeria. \\ ${ }^{3}$ Department of Surveying \& Geoinformatics, Abubakar Tafawa Balewa University, Bauchi, Nigeria.
}

ABSTRACT: The maximum yield of 90,000 $\mathrm{m}^{3} /$ day from the existing Gubi dam in Bauchi will barely meet the water demand beyond 2030 at an average water use of 100 litres per capita/day. For higher water demand of up to 250 litres per capita/day expected in an urban centre, the existing dam capacity is inadequate, and the demand should grow to $253,102 \mathrm{~m}^{3} /$ day by 2037 . This is the rationale for this study, which showed the feasibility of a new dam through technical reviews and analysis of topography, hydrology of the site, field and laboratory investigations, computer analyses and designs. Hydrologic simulation of rainfall-runoff processes for 57 years of rainfall data using the Soil Conservation Service (SCS) method gave an annual runoff volume of $59 \mathrm{Mm}^{3}$ on a stream in Miri, which can be harnessed to assure adequate water supply in the metropolis. This will require the construction of a $25 \mathrm{~m}$ high embankment dam. Topographic survey and analysis indicated that the proposed site has good water retention capability. Although net flow adjustment analysis showed a high evaporation loss of up to $13.5 \mathrm{Mm}^{3}$ annually, seepage loss is expected to be small in view of the underlying basement complex rock formation.

KEYWORDS: Bauchi, basement complex, embankment dam, evaporation, rainfall-runoff processes, water demand.

[Received Apr. 4, 2021; Revised Oct. 19, 2021; Accepted Oct. 24, 2021]

Print ISSN: 0189-9546 | Online ISSN: 2437-2110

\section{INTRODUCTION}

There is a common aphorism that "water is life". As one of the four elements of nature, it is essential to human existence on earth, just like the other three: fire, soil and air. The provision of potable water is one of the cardinal responsibilities of modern government (Japan International Cooperation Agency (JICA), 2014), which can be achieved by development of surface, (Kuria and Vogel, 2014), and ground water resources (Carrard et al., 2019). Abundant precipitation and good topography in a region may indicate that surface water source as being the better alternative to ground water source which is exhaustible (Doro et al., 2020; Healy et al., 2020; Salau and Salaudeen, 2017). Within the Bauchi Local Government Area (LGA), this is even more poignant considering the underlying basement complex rock formation which is known to have poor groundwater retentive capacity, transmission and large population base. In any case, efforts to ensure, potable and sustainable water supply for a given community, are always geared towards the most relevant water resource and its management. A dam can therefore meet the water supply needs more feasibly.

There exists an embankment dam for municipal water supply in Bauchi, with a reservoir capacity of 35 million $\mathrm{m}^{3}$, and daily yield of 90,000 $\mathrm{m}^{3}$ (Gauff Consultants, 2018). The population of Bauchi LGA by the 2006 population census was 359,923 (Federal Government of Nigeria, 2012), which is expected to grow to 1,012,408 by 2037 (Gauff Consultants, 2018). By 2017, the estimated water demand was 67,781 $\mathrm{m}^{3} /$ day and $101,241 \mathrm{~m}^{3} /$ day by 2037 at a per capital demand of
100 litres per day. At this rate, the existing reservoir yield will barely be sufficient to meet demand by 2037. It can be noted that the estimated demands by Gauff Consultant did not consider industrial and commercial demands. At the recommended rate of 250 litres per capita per day for urban centres, the water demand was expected to be as high as $169,452 \mathrm{~m}^{3} /$ day in 2017 and $253,102 \mathrm{~m}^{3} /$ day in 2037 . It is thus evident that the existing dam in Bauchi cannot meet the expected demand currently and, in the future, signifying a serious challenge, which is nonetheless surmountable with pragmatic steps (Balogun et al., 2017). This study was therefore conducted to assess the feasibility of an alternative dam within the Bauchi LGA to meet water demand for the foreseeable future.

Water availability in a catchment is assessed by analysis of stream flow data. In an ungauged catchment where stream flow data are unavailable, the use of simulation models to generate runoff volumes and extreme flows on the intended stream from rainfall data is a necessity (Salaudeen et al., 2016). The rainfall-runoff processes can be simulated by several powerful models that synthesize distinct components (Adnan and Atkinson, 2012; Awadalla and Noor, 1991), such as evapotranspiration, infiltration, detention or depression storage, overland flow and finally stream flow. The slope and timing of the hydrograph from a given storm event, in a catchment, is a function of several physiographic factors, such as rainfall intensity and duration, size, slope, shape, storage and morphology of watershed, land use, and cover, soil type and imperviousness (McCuen, 1989; Basarudin et al., 2014; 
Oyegoke et al. 2020). These factors influence streamflow in a basin.

Advances in computer technology have made possible the development and use of simulation models in hydrology (Doro et al., 2020; Chandwani et al., 2015; Kumar and Tv, 2013). Normally, these models are sets of equations describing various phases of the rainfall-runoff processes and account for water balances through time, of which there are different types based on a wide range of characteristics. The common models used in watershed analysis are: deterministic models (Ahmed and Tsanis, 2016), distributed parameter model (Shrestha and Lohpaisankrit, 2017), semi-distributed models (Hicks and Peacock, 2005; Lang et al., 2016; Mondal et al., 2018; Nyaupane et al., 2018), event-based model (Silva et al., 2016; McCorquodale et al., 2010; Lang et al., 2016), continuous model (Bello, 2018; Johnson et al., 2018) and others (Adham et al., 2014). The more complex models require extensive data, which are often unavailable in Nigeria. For this study, the United States (US) Soil Conservation Service (SCS) method was used to assess the availability of water in the ungauged catchment as has been used by numerous researchers in different regions of the world (e.g. Adham et al., 2014; Ahmed and Tsanis, 2016; Akbari et al., 2014; Husain et al., 2018; Liu et al., 2017; Parhi, 2018).

\section{A. Materials \\ 1) The study site}

The watershed is inscribed approximately by longitude $9^{\circ}$ $35^{\prime}$ and $09^{\circ} 45^{\prime} \mathrm{E}$ and latitude $10^{\circ} 10^{\prime}$ and $10^{\circ} 25^{\prime} \mathrm{N}$. The proposed location of the dam and reservoir is about $6 \mathrm{~km}$ northwest of Miri village on River Shuda, which is a major tributary to River Zaranda. The dam axis cuts through a small farming settlement - Shuda at a section of the river close to the prominent Rehu Hill and other microhills on the right river bank. The elevation at the dam site rises from about $602 \mathrm{~m}$ asl at the river to a peak of $720 \mathrm{~m}$ asl on the Rehu hill and to as high as $1446 \mathrm{~m}$ asl on the southern Zaranda hills that forms the ridge of the watershed divide. The river has a wide flood plain at the dam site of up to $500 \mathrm{~m}$. The bank valley is bounded by a small hill on the right bank that define the edge of the reservoir, and on the left bank by an undulating plain having gentle slopes that rises to a peak of $630 \mathrm{~m}$ asl.

River Shuda has several tributaries that form a dendritic drainage pattern. The two most prominent ones are: one to the south east, and the other to the south west. The entire watershed is located on basement complex rock formation. The two main tributaries are approximately $15 \mathrm{~km}$. Thus, the watershed is almost rectangular, with an estimated area of $151 \mathrm{~km}^{2}$. The vegetation is wooded shrubland. The land use is farming and livestock grazing. The watershed is shown in Figure 1.

\section{B. Methods}

\section{1) The SCS curve number}

SCS model assumes that the volume of runoff $\mathrm{Q}$ depends on the volume of precipitation $\mathrm{P}$ and volume of storage $(\mathrm{S})$ that is available for retention (McCuen, 1989; Kabiri et al., 2013). The actual retention is $\mathrm{P}-\mathrm{Q}$, with an initial abstraction $I_{a}$. The runoff is expressed as in Eq. (1).
$Q=\frac{(P-0.2 S)^{2}}{P+0.8 S}$

$P \geq 0.2 S$

(United State Department of Agriculture, 1986).

where $S$ is the potential storage and the initial abstraction $I_{a}$ is equal to $0.2 \mathrm{~S}$.

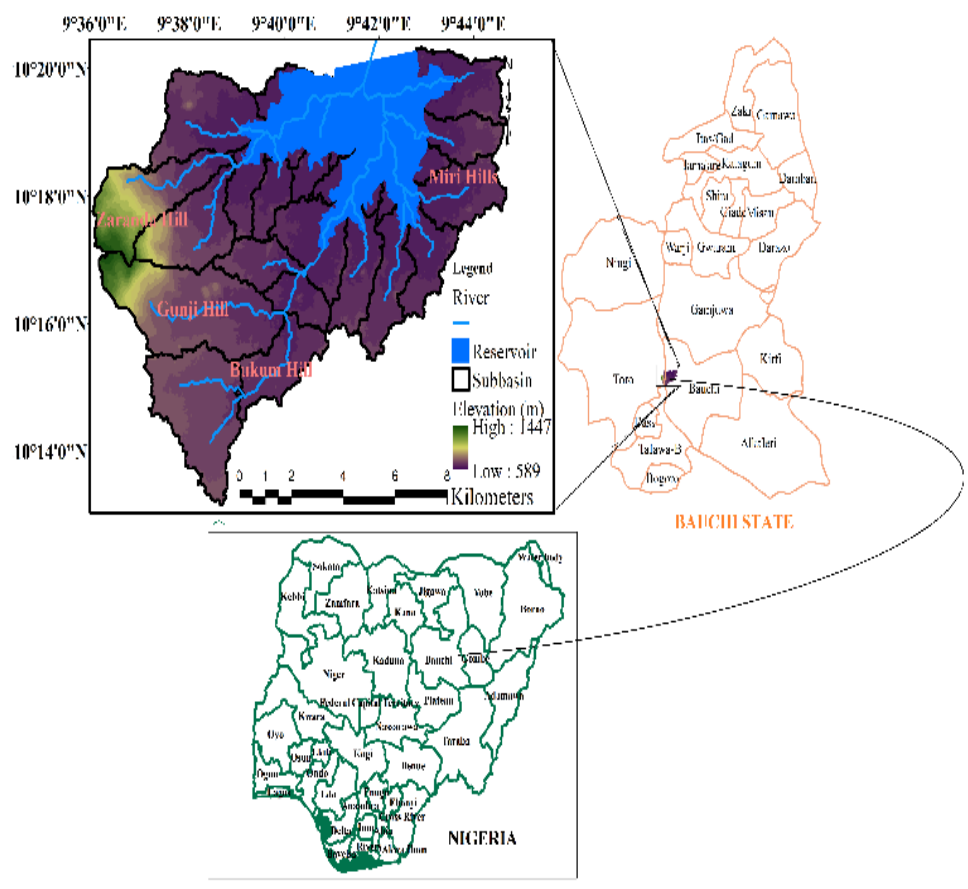

Figure 1: The study location.

This equation has one unknown; the potential maximum retention $\mathrm{S}$, and empirical studies indicate that it can be estimated by Eq. (2).

$$
S=\frac{254000}{C N}-254
$$

$\mathrm{CN}$ is the curve number. All factors influencing $I_{a}$ and $S$ also influence the curve number CN. $S$ is in millimetres. The peak discharge, $q_{p}$, for the unit hydrograph for the sizing of the spillway is given as (McCuen, 1989):

$$
\begin{aligned}
q_{p} & =\frac{484 A}{t_{p}} \\
\text { where } t_{p} \text { is expres } & \\
t_{p} & =\frac{l^{0.8}(S+1)^{0.7}}{1900 Y^{0.5}}
\end{aligned}
$$

where $t_{p}$ is expressed as:

$l$ is the stream course to outfall from the farthest point on the catchment, $Y$ is the average slope in percentage, $A$ is the catchment area.

The SCS developed the runoff curve number index to represent the combined hydrologic effect of soil, land use, agricultural land treatment class, hydrologic condition and 
antecedent soil moisture (Schneider and McCuen, 2005; Soulis and Valiantzas, 2012; Uwizeyimana et al., 2019). These factors are assessed from soil survey maps, site investigations and land use maps. The SCS also developed soil classification system consisting of four groups: denoted by letter A, B, C and $\mathrm{D}$; ranging from deep sand, deep loess, to heavy plastic clays (United State Department of Agriculture, 1986). The classification of land cover is in three factors: land use, treatment or practice and hydrologic condition, while there are altogether fifteen different land uses, and three hydrologic conditions (poor, fair, good) reflecting the level of land management (Uwizeyimana et al., 2019). The curve number is selected from table depending on the antecedent moisture condition. SCS developed three antecedent moisture conditions, labelled I, II and III (McCuen, 1989; Ebrahimian et al., 2012).

Other aspects of the study included topographic reviews and survey, geologic reviews and mapping, geotechnical investigations of dam and other appurtenant structures and materials of construction. Detailed information on these aspects can be found in Upper Benue Development Phase I (Diyam Consultants, 1980).

The hydrologic assessment of water availability was performed using the SCS method. Monthly rainfall data were acquired for Bauchi Station from 1901 to 1965 and 1982 to 2019 , while the land uses of the watershed were evaluated from software analysis of the recent satellite images of the watershed, for each of which the curve numbers were determined for the different antecedent moisture conditions. Condition I was used in computing runoff for the dry months of November-March, while conditions II and III were used for the remaining months depending on the cumulative monthly rainfall.

The curve number was determined for the basin based on the following data: Land use (Pasture or range, farmstead, fallow land and forestry); Soil group: B moderate to deep sandy loam; C - shallow sandy loam with impervious bare rock areas (Kabiri et al., 2013; United State Department of Agriculture, 1986). The hydrologic condition was noted to be fair. Based on these data, the curve number for the three antecedent conditions were evaluated as shown in Table 1.

Table 1: Curve number for the watershed.

\begin{tabular}{ll}
\hline Antecedent Moisture Condition & CN \\
\hline I & 55 \\
II & 74 \\
III & 87 \\
\hline
\end{tabular}

The model was implemented on spreadsheet for the 57 years of rainfall data used for the modelling.

The watershed characteristics were evaluated from topographic maps, from which the following parameters of the catchment were obtained: watershed area and basin slope; while the vegetal cover was derived from the classified Landsat images. Soil classification groups were obtained from Bauchi Atlas, 1987. The inflow design hydrograph was prepared using the SCS method by convolution of the unit hydrograph and the excess rainfall for 10,000-year flood event and routed through the reservoir to obtain the outflow design hydrograph that was the basis for sizing of the spillway.

Net flow adjustment analysis was performed to determine the effect of evaporation on reservoir operation. Geotechnical investigation was conducted along the proposed dam axis and general reservoir area and the watershed. This was intended to assess the foundation conditions and availability of suitable construction materials. Standard laboratory tests were conducted on the collected samples in accordance with BS 1377 (1990). The materials were classified using the Unified Soil Classification System as contained in Das (2006).

Preliminary assessment of the geologic condition was made by review of geologic maps and report on existing dam within Bauchi metropolis. An earthfill embankment dam was designed using the hydrologic, topographic, land survey works, geotechnical data and geologic evaluations of the proposed dam site.

\section{A. Water Availability}

\section{RESULTS AND DISCUSSION}

The annual rainfall in the watershed varies from 778 to $1,472 \mathrm{~mm}$ with an average of $1080 \mathrm{~mm}$ and standard deviation of $149 \mathrm{~mm}$. This gave a small coefficient of variation of $14 \%$ over the years of record used for the simulation. The statistics of the data and result of the rainfall-runoff simulation using the SCS method are shown in Table 2 for the periods, 1906-1965 and 1982-2019. The model predicted a mean annual runoff volume of $59.32 \mathrm{Mm}^{3}$ and $55.03 \mathrm{Mm}^{3}$ for the watershed area of $151 \mathrm{~km}^{2}$ for the two periods, which represent $393 \mathrm{~mm}$ and $364 \mathrm{~mm}$ of runoff depth, respectively. Nonetheless, the runoff volume of $393 \mathrm{~mm}$ was considered for the design. This is $36 \%$ of the total precipitation volume, which may be considered conservative considering the topography, soil and land use patterns, vegetation, and geology of the watershed.

In a nearby catchment of the Gongola River at Bagel on Dass Road, the annual runoff volume over a watershed area of $1,560 \mathrm{~km}^{2}$ was found to be $501 \mathrm{Mm}^{3}$ for average annual precipitation of $1050 \mathrm{~mm}$. This translated to an annual runoff volume of $321 \mathrm{~mm}$ representing $30 \%$ of the annual precipitation (Diyam Consultants, 1977). Thus, the slightly higher runoff coefficients obtained for the smaller Shuda catchment by rainfall-runoff simulation can be considered to be good for the sizing of the reservoir capacity. Figures 2 (a) and (c) show the annual rainfall depth and the predicted runoff volumes for the simulated years of 1905-1965, while Fig 2 (b) and (d) present annual rainfall depth and the simulated runoff volume, but for the period of 1982-2019. 
Table 2: Statistics of the rainfall and simulated runoff data.

\begin{tabular}{|c|c|c|c|c|c|c|}
\hline \multirow{3}{*}{ Parameter } & \multicolumn{3}{|c|}{ 1906-1965 } & \multicolumn{3}{|c|}{ 1982-2019 } \\
\hline & \multirow{2}{*}{$\begin{array}{c}\text { Annual } \\
\text { rainfall }(\mathbf{m m})\end{array}$} & \multicolumn{2}{|c|}{ Annual simulated runoff } & \multirow{2}{*}{$\begin{array}{c}\text { Annual } \\
\text { rainfall }(\mathrm{mm})\end{array}$} & \multicolumn{2}{|c|}{ Annual simulated runoff } \\
\hline & & $(\mathbf{m m})$ & $\left(\mathbf{M m}^{3}\right)$ & & $(\mathbf{m m})$ & $\left(\mathbf{M m}^{3}\right)$ \\
\hline Mean & 1,080 & 393 & 59.32 & 1,067 & 364 & 55.03 \\
\hline Standard deviation & 149 & 28 & 4.25 & 311 & 95 & 14.35 \\
\hline Skewness coefficient & 1 & 0 & 0.58 & 1 & 1 & 1.44 \\
\hline Coefficient of variation (\%) & 14 & 7 & 7.16 & 29.15 & 41 & 41.23 \\
\hline Minimum & 778 & 175 & 26.49 & 667 & 176 & 39.20 \\
\hline Maximum & 1,472 & 725 & 109.42 & 1,897 & 1,163 & 209.10 \\
\hline
\end{tabular}

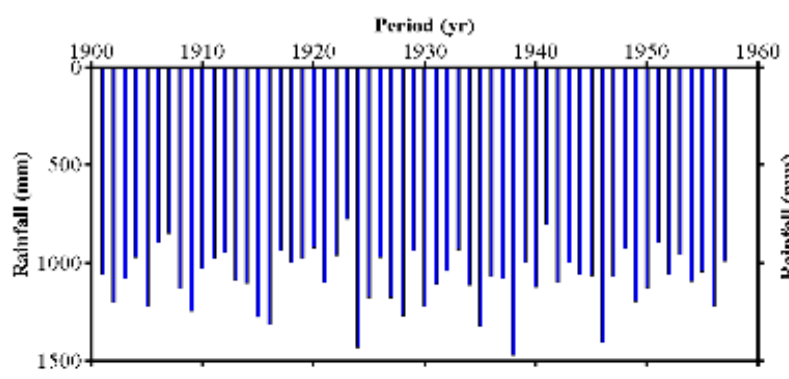

(a)

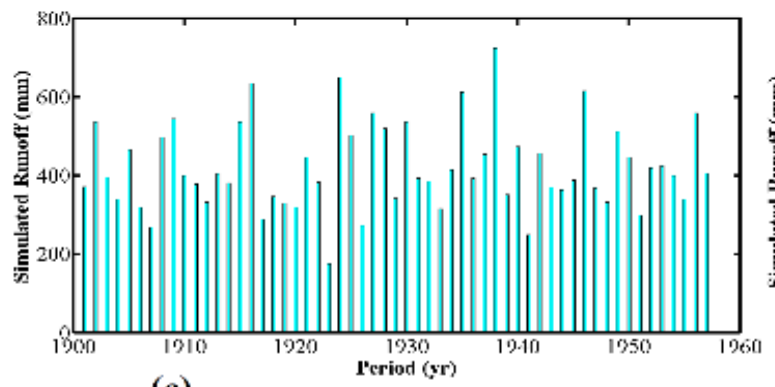

(c)

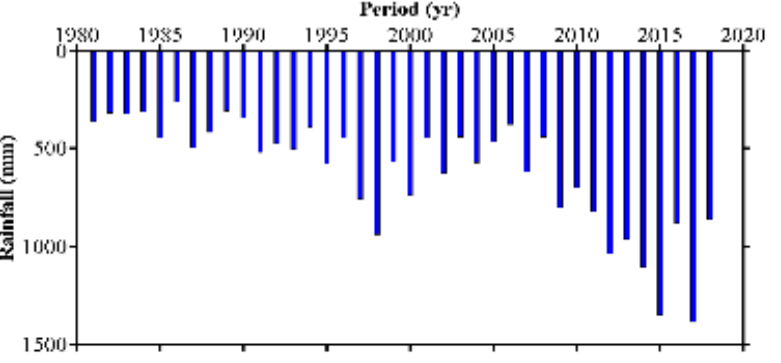

(b)

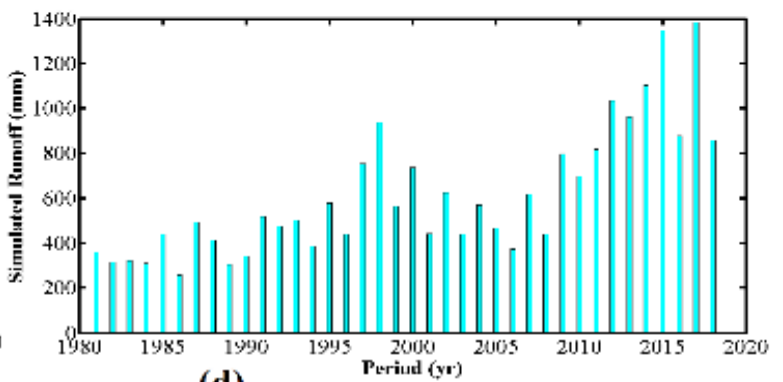

(d)

Figure 2: (a) and (b) present the Annual Rainfall Climatology in Millimetres from 1905-1965 and 1982-2019 respectively (Source: NiMET); while (c) and (d) show the Simulated Annual Runoff Depth in Millimetres for the Watershed in this Study.

Positive trends in mean annual precipitation were noted over the study area for the two epochs vis: the early (1905-1965) and the late (1982-2019) periods. However, the increasing trend in the late period is significant at $95 \%$ confidence interval, corroborating the claims on climate change influence on the rainfall variability in the region (Salaudeen et al, 2021). Despite the higher magnitude of rainfall amount recently, the early period has longer years of record with less variability as compared to the later. Furthermore, the mean annual rainfall amounts and the consequent runoff volumes are similar. Since the interest is to determine the annual runoff volume for sizing the reservoir and to as well as to allow efficient water resource allocation, the rainfall estimates of the early period was selected.

\section{B. Reservoir Capacity}

The processing of available topographic maps and detailed field surveys by Total Station yielded the reservoir characteristics shown in Figure 3. It is evident from the curve

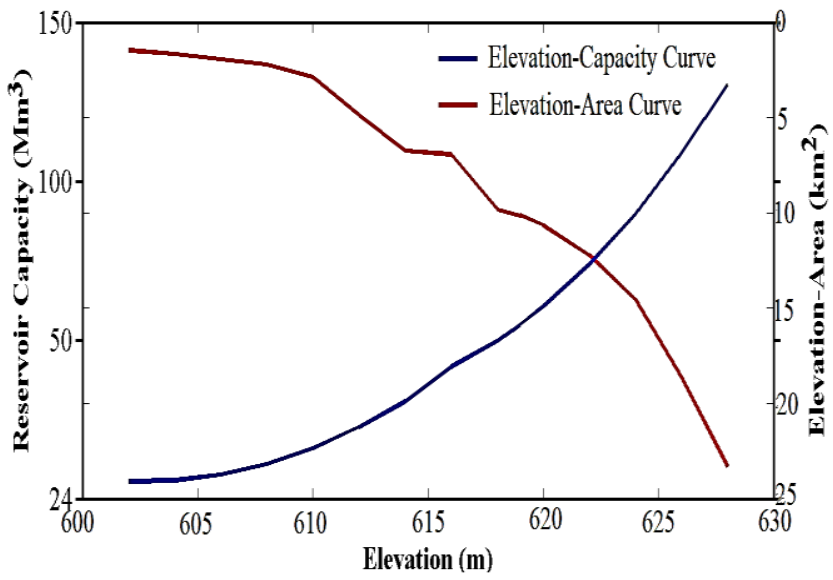

Figure 3: Reservoir Elevation-Area-Capacity Curve.

that the selected dam location has good water retention capability. At $59 \mathrm{Mm}^{3}$ storage capacity, the retention water level is $620 \mathrm{~m}$ at $10.65 \mathrm{~km}^{2}$ inundation surface area. The retention water level can however be increased to $622 \mathrm{~m}$ in 
order to increase the gross storage capacity to $75 \mathrm{Mm}^{3}$ and 12.5 $\mathrm{km}^{2}$ surface area at full supply level. This will permit over-year storage to meet water requirements in drier years. Increasing the reservoir capacity above this level would increase the resettlement costs due to villages upstream that may be close to the reservoir rim. Evaporation losses were evaluated by net flow adjustment analysis at $13.5 \mathrm{Mm}^{3}$ per annum. But seepage loss through the embankment and foundation is expected to be minimal in view of grouting of the bedrock and removal of the overburden.

\section{Water Supply Potential}

The available water for use is based on an estimated annual runoff volume of $59 \mathrm{Mm}^{3}$, which is distributed as shown in Table 3. At per capital water demand of 250 litres per day and $80 \%$ abstraction, the reservoir can serve a population of 517,200 . When combined with the capacity of the existing dam at Gubi, the combined capacity of the two dams can meet water demand beyond 2037. Since the population of the rural communities is less than this value, the balance can be deployed for irrigation of arable land in the downstream valley. The water demand of Miri and its environs is estimated to be of the order of $5.695 \mathrm{Mm}^{3}$ per annum, which is $12 \%$ of the estimated annual yield of $47.2 \mathrm{Mm}^{3}$ the period before the full draft of the reservoir potential, irrigated agriculture can be undertaken to a maximum area of 2,000 ha.

Table 3: Water availability and allocation.

\begin{tabular}{lc}
\hline Uses & Annual Volume $\left(\mathbf{M m}^{\mathbf{3}}\right)$ \\
\hline Domestic water supply & 7.3 \\
Irrigation & 31 \\
Net Losses (Evaporation and storage) & 13.5 \\
Dead storage & 7.5 \\
Availability & 59 \\
\hline
\end{tabular}

\section{Reservoir Sedimentation}

In setting the dead storage for the reservoir, the expected inflow of sediments into the reservoir from the watershed is first evaluated. This should have been based on the sediment load measurement on the river, which data were not existent therefore for the study, information in literature of previous sediment yield studies in the adjacent Gongola and Bunga basins was relied on.

Diyam and Parkman (1977) have reviewed the sediment yields on the Gongola basin based on the previous works and two other consultants - ShawMont Ltd and Consulint Ltd. The report indicated that the expected sediment yield ranges from $0.15-0.17 \mathrm{~mm}$ from the catchment area. In the absence of data specific to the site under study, a reservoir sedimentation estimate of $0.17 \mathrm{~mm}$ on Gongola River at Dindima was adopted. The annual sediment production rate is $25,670 \mathrm{~m}^{3}$. Using a sediment bulk density of $1500 \mathrm{~kg} / \mathrm{m}^{3}$, the sediment yield comes to 38,505 tonnes per year. For the 100-year useful life of the reservoir, the total sediment load will be 3.85 million tonnes. A provision of minimum value of $2.57 \mathrm{Mm}^{3}$ was therefore made for dead storage. A more conservative approach may be to adopt $10 \%$ of the reservoir capacity at full supply level as the dead storage (United States Bureau of Reclamation, 1987).

\section{E. Evaporation Losses}

For the reservoir site, the main natural loss is due to evaporation. Seepage loss may also be low because the reservoir site is underlain by relatively impervious basement complex formation. Accurate assessment of the losses due to evaporation requires detailed information on the climatic factors such as temperature, humidity, windspeed and solar radiation. Where these data are not available at meteorological station close to the site, data collected from evaporation pan can be used to assess the level of losses due to evaporation. Direct rainfall on the reservoir site is a gain that must be accounted for in the water balance. This process is referred to as net flow adjustment. It refers to accounting for water losses or gain from the reservoirsuch as evaporation, seepage, and direct rainfall on reservoir that must be deducted from available water.

Pan evaporation data from Bauchi station were analysed to determine open surface water evaporation at the reservoir. Derivation of open reservoir evaporation from evaporation pan data often results in high estimates. To account for this, Diyam (1986) suggested the reduction of the computed evaporation by $5 \%$ to arrive at the normal year evaporation.

The monthly runoff depth is obtained by dividing the monthly runoff volume by the catchment area. The direct runoff on the reservoir must be substracted from the inflow to the reservoir to maintain the water balance. The net flow adjustment (NFA) is given as:

$$
N F A=E+R-R_{S}
$$

where $\mathrm{E}=$ evaporation $(\mathrm{mm}) ; \mathrm{R}=$ Runoff loss $(\mathrm{mm})$ and $\mathrm{R}_{\mathrm{s}}=$ the direct rainfall on the reservoir (mm), (McCuen, 1989).

This equation is integrated over the current reservoir surface area.

The change in the volume of water held in the reservoir in any month which is due to natural inflow and outflow is evaluated using Eq.(6) (McCuen, 1989).

$$
V=I-A * N F A
$$

where $\mathrm{V}$ is the change in stored water volume at the end of the month; I = total natural inflow during the month; $\mathrm{A}=$ average reservoir surface area during the month; NFA is the net flow adjustment for the month.

The net adjustments was computed for an average year of reservoir operation, as shown in Table 4. It is evident that there is a net gain in August and a very small loss in July and September, but the highest evaporation loss occurs in March of any year. The analysis showed the monthly losses during the dry months to be of the order of $1.80 \times 10^{6} \mathrm{~m}^{3}$, with a range of $1.58-2.62 \times 10^{6} \mathrm{~m}^{3}$. The total loss per annum is about 13.5 $\mathrm{Mm}^{3}$. This estimate is based on a daily draft of $3 \mathrm{~m}^{3} / \mathrm{s}$ for water 
Table 4: Net flow adjustments.

\begin{tabular}{|c|c|c|c|c|c|}
\hline \multirow{2}{*}{ Months } & \multicolumn{3}{|c|}{ Factors (mm) } & \multirow{2}{*}{$\begin{array}{c}\text { Net flow adjustment } \\
(\mathbf{m m})\end{array}$} & \multirow{2}{*}{$\begin{array}{c}\text { Evaporation loss } \\
\left(\mathrm{Mm}^{3}\right)\end{array}$} \\
\hline & $\begin{array}{c}\text { Normal year } \\
\text { evaporation }\end{array}$ & $\begin{array}{c}\text { Rainfall on } \\
\text { reservoir }\end{array}$ & $\begin{array}{c}\text { Runoff lost } \\
\text { from reservoir }\end{array}$ & & \\
\hline January & 182.00 & 0 & 0 & 182.00 & 1.58 \\
\hline February & 215.00 & 0 & 0 & 214.50 & 2.07 \\
\hline March & 305.00 & 5.00 & 0 & 299.85 & 2.62 \\
\hline April & 298.00 & 34.00 & 0 & 263.70 & 1.54 \\
\hline May & 254.00 & 89.00 & 9.00 & 174.10 & -0.11 \\
\hline June & 203.00 & 147.00 & 36.00 & 91.50 & 0.12 \\
\hline July & 172.00 & 251.00 & 107.00 & 27.75 & 0.11 \\
\hline August & 148.00 & 338.00 & 176.00 & -14.25 & -0.15 \\
\hline September & 158.00 & 179.00 & 56.00 & 35.25 & 0.44 \\
\hline October & 177.00 & 36.00 & 0 & 140.80 & 1.79 \\
\hline November & 168.00 & 1.00 & 0 & 166.70 & 1.80 \\
\hline December & 163.00 & 0 & 0 & 163.15 & 1.71 \\
\hline Annual & 2441.05 & 1080.00 & 384.00 & 1745.05 & 13.51 \\
\hline
\end{tabular}

supply and irrigation. It was also assumed that the reservoir will be at full supply level at the start of the reservoir operation in November of any year. Details of the results are shown in Table 4.

The changes in reservoir capacity with time in any year are shown in Figure 4. The lowest capacity was found to be in May at which the reservoir volume may be as low as $14 \mathrm{Mm}^{3}$. However, refilling commences after the onset of the raining season and full reservoir capacity is attained just as the next dry season sets in November.

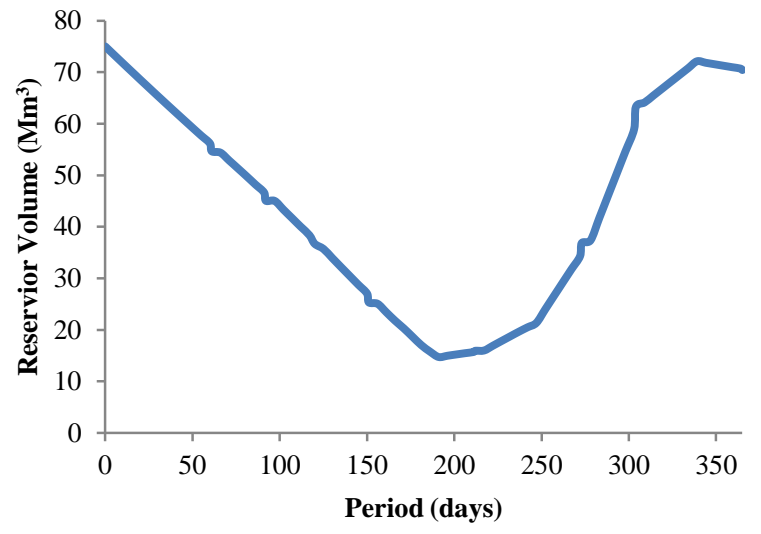

Figure 4: Variation of Reservoir Volume for Days of the Year starting from November.

\section{F. The Dam and Appurtenant Structures}

1) The dam

The proposed dam is a conventional zoned earthfill dam, $1,500 \mathrm{~m}$ long with a crest level at $625 \mathrm{~m}$ asl (see Figure 5). The core would consist of borrowed silty clay or sandy clay material that is available in large quantities in the dam and reservoir sites. The outer pervious shell consists of rock material which will be obtained from rock outcrops available in the outer edges of the basin beyond the flood plain. The drainage and filter materials are available on the river bed itself in large quantities upstream and downstream of the dam axis. Any shortfall is expected to be obtained from crushed stones in an established quarry. The riprap for upstream and downstream slope protection is expected to come from excavations for the spillway and the established quarry. A line grouting of the dam axis was required to assure of low permeability through the rock formation with a maximum penetration of $20 \mathrm{~m}$.

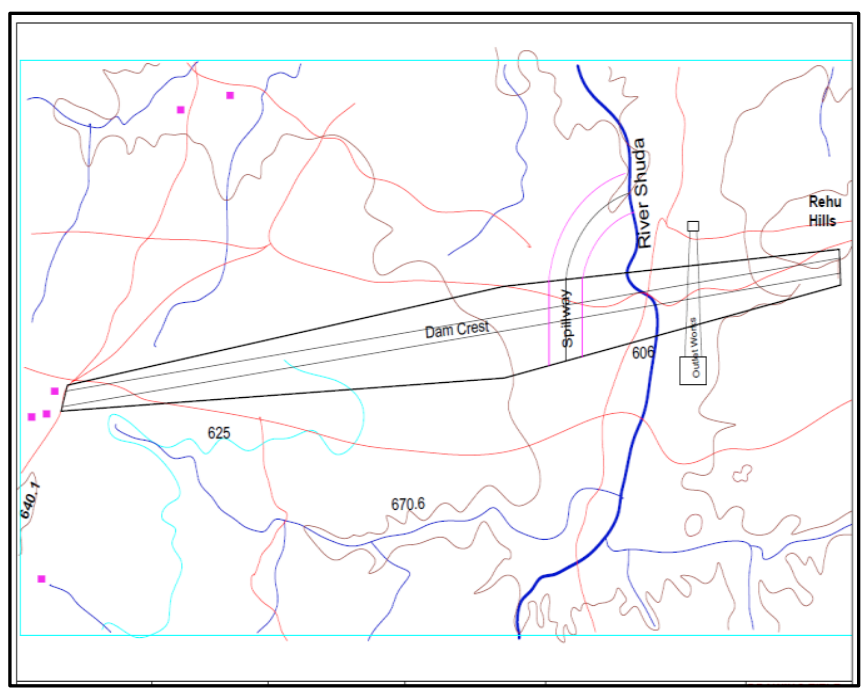

Figure 5: Layout of the dam and its appurtenances. 
The basic properties of the materials of the embankment suggested based on laboratory testing of soil samples are shown in Table5.

Table 5: Engineering properties of embankment materials.

\begin{tabular}{|c|c|c|}
\hline Material & $\begin{array}{c}\text { Cohesion } C^{\prime} \\
\left(\mathbf{k N} / \mathbf{m}^{2}\right)\end{array}$ & $\begin{array}{c}\text { Angle of } \\
\text { Friction } \\
\left.\Phi,{ }_{(}{ }^{\circ}\right)\end{array}$ \\
\hline Core & 18 & 15 \\
\hline Shoulder & 6 & 30 \\
\hline Drainage Filter & 0 & 35 \\
\hline In-situ top soil & 15 & 20 \\
\hline $\begin{array}{l}\text { In-situ medium/ } \\
\text { Slightly weathered rock }\end{array}$ & 15 & 30 \\
\hline
\end{tabular}

Typical cross section of the dam is shown in Figure 6. The dam was designed in line with the provisions of (United States Bureau of Reclamation, 1987).

\section{2) Appurtenant structure}

The water supply and outlet work were sited some $100 \mathrm{~m}$ distance on the right bank of the river channel, to discharge 3.37 and $1.31 \mathrm{~m}^{3} / \mathrm{s}$ at full supply and minimum operating water levels of 622 and $608 \mathrm{~m}$ respectively. It comprises of a square bell mouthed intake and a bulkhead gate, aeration duct and trash rack; steel lined single pressure conduct $0.75 \mathrm{~m}$ in diameter and $125 \mathrm{~m}$ long and outlet structure consisting of 0.60 $\mathrm{m}$ diameter Howell-Bunger valve with upstream maintenance gate.

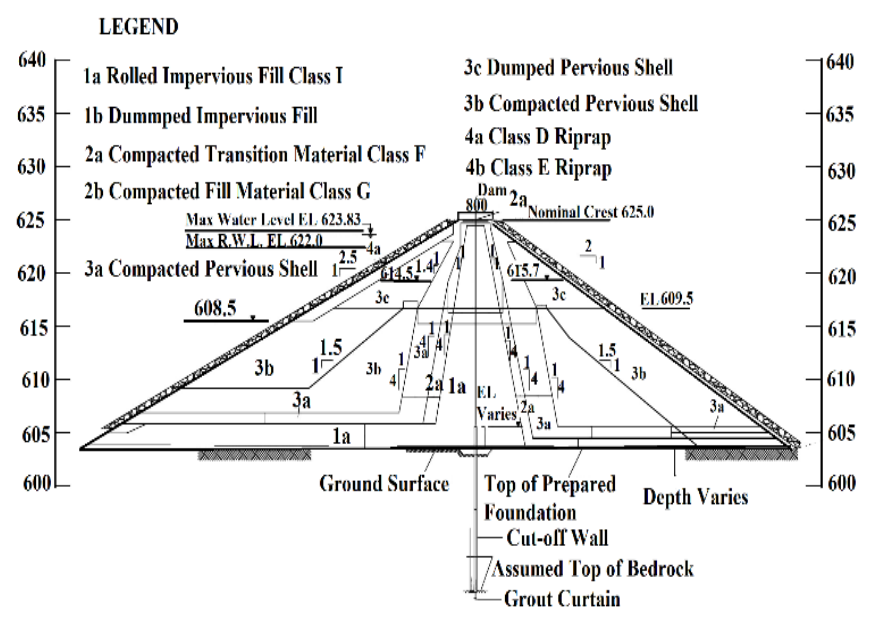

Figure 6: Maximum dam cross-section at $\mathrm{CH} 0+612.5$.

\section{3) Spillway}

The spillway is an ogee overflow weir with stilling basin. The width is $75 \mathrm{~m}$ and a design discharge of $407 \mathrm{~m}^{3} / \mathrm{s}$ at 10,000 -year return period at $623.14 \mathrm{~m}$ flood level. The embankment was also designed to resist wave action and wind set-up from simultaneous 10-year storm blowing against the dam embankment. In addition to the spillway, a fuse plug may be added to release flood from a 10,000-year flood event. The dyke is located on the left embankment with a crest level of $622 \mathrm{~m}$ and is $40 \mathrm{~m}$ in width. It is expected to be over topped and washed off in a case of a maximum probable flood. Figure 7 shows the inflow and outflow design hydrographs for the design of the spillway and stilling basin, while Figure 8 presents the inflow and outflow design hydrographs for different spillway lengths. The principal dimensions of proposed dam are shown in Table 6.
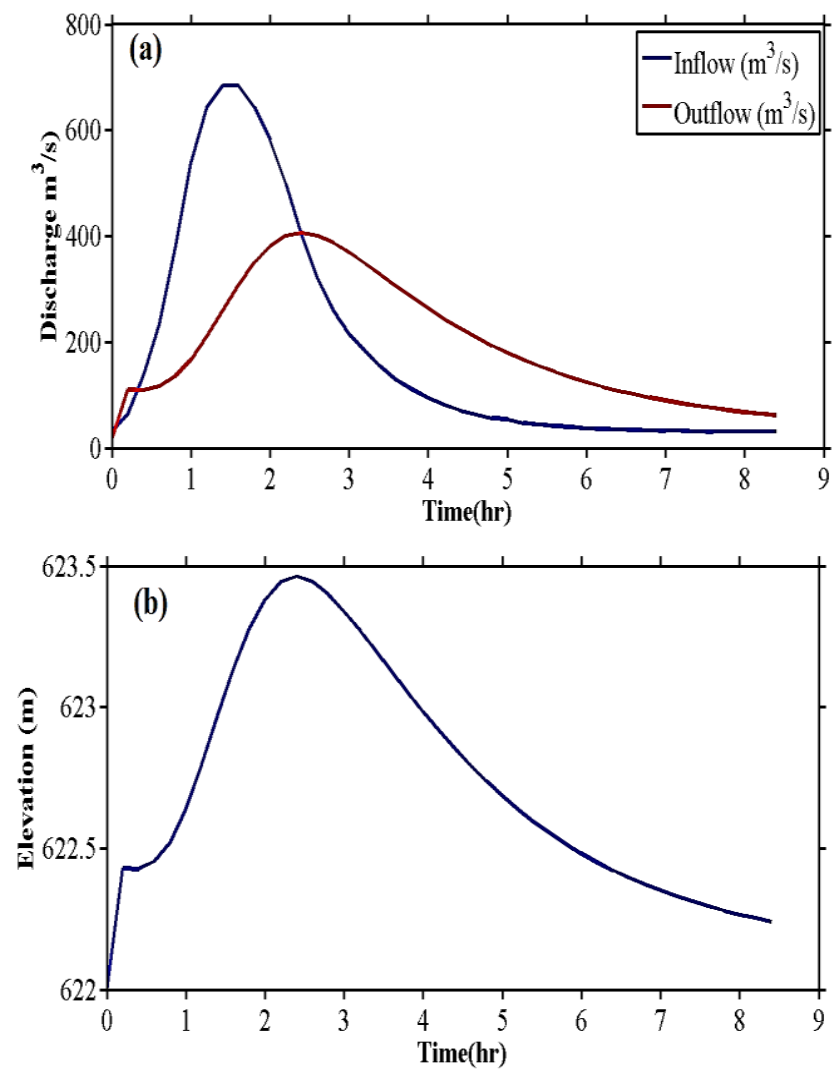

Figure 7: (a) Inflow and outflow design hydrographs (b) Water surface level for the spillway.

Table 6: Proposed Shuda dam principal dimensions.

\begin{tabular}{lc}
\hline Hydrology & Parameters \\
\hline Catchment Area & $151 \mathrm{~km}^{2}$ \\
Average Annual Rainfall & $1080 \mathrm{~mm}$ \\
Average Annual Inflow & $59.32 \mathrm{Mm}^{3}$ \\
Inflow Design Flood (1: 10,000) & $684 \mathrm{~m}^{3} / \mathrm{s}$ \\
Outflow Design Flood (1: 10,000) & $407 \mathrm{~m}^{3} / \mathrm{s}$ \\
3-Day volume & $14 \mathrm{Mm}^{3}$ \\
Reservoir & \\
Volume & $74.00 \mathrm{Mm}^{3}$ \\
Area & $12.23 \mathrm{~km}^{2}$ \\
Retention Water Level (RWL) & $622.00 \mathrm{~m}$ \\
1: 10,000-year Flood Level & $623.14 \mathrm{~m}$ \\
Minimum Operating Water Level & $606.00 \mathrm{~m}$ \\
Dam & Earthfill Type \\
Crest Elevation & $625 \mathrm{~m}$ \\
Maximum Height & $22 \mathrm{~m}$ \\
Length of Crest & $1,500 \mathrm{~m}$ \\
Main Spillway (Outflow) Type & Free Flow \\
Crest Level & $625 \mathrm{~m}$ \\
Crest Length & $1500 \mathrm{~m}$ \\
Maximum Discharge Outlet Works & $310 \mathrm{~m} / \mathrm{s}$ \\
Control & Howell-Bunger Valve \\
Capacity & $3.37 \mathrm{~m} 3 / \mathrm{s}$ \\
\hline
\end{tabular}


Economic design of the spillway is based on the 100-year flood event. Where special protection against failure is a matter of government policy, the spillway design can be based on the 10,000-year flood event or the probable maximum flood. The cost however will be higher as the length of the spillway will be high to maintain a minimum freeboard.

The summary of results for 10,000 flood events are shown in Figure 8 for spillway length of 50 m, 60 m, 70 m, 75 m, 80 $\mathrm{m}$ and $100 \mathrm{~m}$ respectively. It is evident from the figures that the lowest reservoir levels were obtained for the longest spillway, which incidenally is the costliest. It is proposed to limit the spillway length to a maximum length of $80 \mathrm{~m}$ for economic consideration.

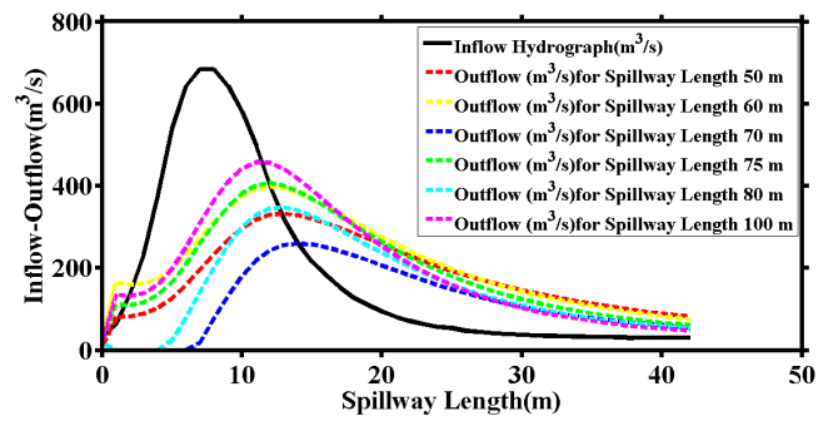

Figure 8: Inflow and outflow design flood for different spillway length at 10,000-yr flood event.

The minimum freeboard for the different stom events were assessed as shown in Table 7. The smalller spillway length has the lowest freeboard which may be inadequate on safety grounds. It is evident that the spillway length that meet the requirement for the minimum freeboard based on the fetch and wind factors is $75 \mathrm{~m}$. This gave a freeboard of $1.85 \mathrm{~m}$, which is comparable to the minimum recommended value of $1.80 \mathrm{~m}$. Details of this are contained in the (United States Bureau of Reclamation, 1987).

Table 7: Summary of reservoir routing results for 10,000-year flood event.

\begin{tabular}{cccccc}
\hline $\begin{array}{c}\text { Return } \\
\text { Period, } \\
\text { yrs }\end{array}$ & $\begin{array}{c}\text { Spillway } \\
\text { Crest } \\
\text { Length } \\
(\mathbf{m})\end{array}$ & $\begin{array}{c}\text { Dam } \\
\text { Crest } \\
\text { Level } \\
(\mathbf{m})\end{array}$ & $\begin{array}{c}\text { Maximum } \\
\text { Reservoir } \\
\text { level (m) }\end{array}$ & $\begin{array}{c}\text { Maximum } \\
\text { Outflow } \\
\left(\mathbf{m}^{3} / \mathbf{s}\right)\end{array}$ & $\begin{array}{c}\text { Minimum } \\
\text { Freeboard } \\
(\mathbf{m})\end{array}$ \\
\hline 10,000 & 50 & 625 & 623.33 & 253.63 & 1.67 \\
10,000 & 60 & 625 & 623.77 & 397.94 & 1.23 \\
10,000 & 75 & 625 & 623.14 & 309.76 & 1.86 \\
10,000 & 80 & 625 & 622.93 & 248.4 & 2.07 \\
10,000 & 100 & 625 & 622.96 & 347.99 & 2.04 \\
\hline
\end{tabular}

\section{G. Geological and Geotechnical Assessment of Dam and Reservoir Sites \\ 1) Foundation conditions}

Investigation of the foundation of the dam site was carried out by geological mapping and test pits. The valley is U- shaped, with wide alluvial area of about $500 \mathrm{~m}$. The abutments consist of rock outcrop on the right, of more than $30 \mathrm{~m}$ high. The foundation of the dam consists of basement complex of coarse-grained feldspar-rich granite but highly weathered at the surface and white medium to coarse basement complex rock with feldspar crystals. This is found below the weathered zone of the rock with larger thickness and monolith. Permeability test was performed on the foundation materials with the following indicative values:

Residual Clayey material: $\mathrm{k}<10^{-6} \mathrm{~cm} / \mathrm{s}-$ impervious Old alluvium: $10^{-3}-10^{-5} \mathrm{~cm} / \mathrm{s}-$ low permeability Weathered basement complex: $10^{-3}-10^{-6} \mathrm{~cm} / \mathrm{s}$; Sound basement complex: $10^{-5}-10^{-7} \mathrm{~cm} / \mathrm{s}$.

\section{2) Reservoir site condition}

There is only one geological formation found in the catchment area, which is: medium to coarse grained basement complex. This forms the underlying formation of the reservoir site. Soil cover on the rock formation was found to be generally moderately deep at the flood plain of more than $4 \mathrm{~m}$ and shallow on the undulating plains. This soil type will not present stability problem in the absence of notable earthen hills and sudden reservoir drawdown. The reservoir rim will therefore be stable.

The hydrogeology of the reservoir site is a reflection of the underlying formation. The basement complex rock is not known to permit high water loss. The head of water in the reservoir overlying the formation is generally low, less than 20 $\mathrm{m}$. In addition, fine sediment deposit after impoundment will form a low-permeability blanket between the water and the rock, which will further reduce seepage loss with time. It is therefore concluded that water loss through the reservoir site will be moderate but is expected to be low and even less with time.

\section{CONCLUSION}

There is need to meet the perennial water shortage in several villages on the watershed of River Shuda by developing the abundant water resources of the basin. This can be achieved by constructing the Shuda dam. This work has shown the feasibility of the project, through technical reviews, field and laboratory investigations, computer analyses and designs. The dam project, if implemented, has the capacity to meet water supply needs of several communities to the tune of 7.3 $\mathrm{Mm}^{3}$ per annum and irrigation requirement of up to $31 \mathrm{Mm}^{3}$ to boost local economy. The project will require a $1,500 \mathrm{~m}$ long zoned earthfill dam to be constructed on the river at about $6 \mathrm{~km}$ south west of Miri village. The maximum height of the dam is $22 \mathrm{~m}$ at a full supply elevation of $622 \mathrm{~m}$ and dam crest elevation of $625 \mathrm{~m}$ a.s.l. The mean annual runoff volume is 59 $\mathrm{Mm}^{3}$, while the reservoir capacity was selected to be $75 \mathrm{Mm}^{3}$ to allow for over-year storage.

Topographic, geological and geotechnical investigations have shown that the selected site has good water retention 
capabilities, the dam and reservoirs being essentially on basement complex rock formation. The choice of dam type was based on the availability of impervious and pervious materials in abundant quantities in the flood plain, river bed and general reservoir area. The presence of several outcrops in the reservoir site indicates easy access to sufficient quantities of highquality crushed stone aggregates and riprap for slope protection. The dam is designed with a free flow Ogee spillway with a discharge capacity of $407 \mathrm{~m}^{3} / \mathrm{s}$ at 10,000-year recurrence interval. An outlet work with a maximum discharge capacity of $4.84 \mathrm{~m}^{3} / \mathrm{s}$ was designed to meet water supply and irrigation requirements.

\section{REFERENCES}

Adham, M.I.; S.M. Shirazi, F. Othman, S. Rahman, Z Yusop, and Z. Ismail (2014). Runoff Potentiality of a Watershed through SCS and Functional Data Analysis Technique. Sci. World J. 2014: 1-15.

Adnan, N.A. and Atkinson, P.M. (2012). Remote Sensing of River Bathymetry for use in Hydraulic Model Prediction of Flood Inundation. IEEE 8th International Colloquium on Signal Processing and its Applications (CSPA): 159-163.

Ahmed, S. and Tsanis, I. (2016). Hydrologic and Hydraulic Impact of Climate Change on Lake Ontario Tributary. American J. of Water Resour. 4 (1): 1-15.

Akbari, A.; G. Mozafari, M. Fanodi, and M.S. Hemmesy. (2014). Impact of Landuse Change on River Floodplain using Public Domain Hydraulic Model. Modern Appl. Sci. 8 (5): 80-86.

Awadalla, S. and Noor, I.M. (1991). Induced Climate Change on Surface Runoff in Kelantan Malaysia. Int. J. Water Resour. Dev. 7 (1): 53-59.

Balogun, I.I.; A.O. Sojobi, E. Galkaye, and G. Mannina (2017). Public Water Supply in Lagos State, Nigeria: Review of Importance and Challenges, Status and Concerns and Pragmatic Solutions. Cogent Eng. 4 (1): 1-21.

Basarudin, Z.; N.A. Adnan, A.R.A. Latif, W. Tahir and N. Syafiqah (2014). Event-Based Rainfall-Runoff Modelling of the Kelantan River Basin. IOP Conference Series: Earth and Environmental Science: 1-6.

Bello, A-A. (2018). Modelling the Impacts of Land-use and Climate Change in Skudai River Watershed. Unpublished $\mathrm{PhD}$ Thesis, Department of Hydraulics and Hydrology, Universiti Teknologi Malaysia, Skudai, Johor Bahru, Malaysia.

Carrard, N., Foster, T. and Willetts, J. (2019). Groundwater as a Source of Drinking Water in Southeast Asia and the Pacific: A Multi-Country Review of Current Reliance and Resource Concerns. Water. 11 (8): 1-20.

Chandwani, V.; S.K. Vyas, V. Agrawal, and G. Sharma (2015). Soft Computing Approach for Rainfall-Runoff Modelling: A Review. Aquatic Procedia. 4: $1054-1061$.

Das, B.M. (2006). Principles of Geotechnical Engineering. 5th ed. Canada, Chris Carson.
Diyam Consultants (1977). Upper Benue Development Phase I - Draft Report on the Gongola Basin. Unpublished report.

Diyam Consultants (1980). Gongola Hydrology. Upper Benue River Basin Development Authority. Unpublished report.

Doro, K., Ehosioke, S. and Aizebeokhai, A. (2020). Sustainable Soil and Water Resources Management in Nigeria: The Need for a Data-Driven Policy Approach. Sustainability. 12 (10): 1-21.

Ebrahimian, M.; A.A. Nuruddin; M.A.B.M. MohdSoom and A.M. Sood. (2012). Application of NRCS-Curve Number Method for Runoff Estimation in a Mountainous Watershed. Caspian J. Env. Sci. 10 (1):103-114.

Federal Government of Nigeria (2012). Annual Abstract of Statistics. In: National Bureau of Statistics (ed.). Abuja: www.nigerianstat.gov.ng.

Gauff Consultants (2018). Improvement of the Urban Water Supply Scheme in Bauchi Metropolis: Study Report Activity III: Feasibility Studies. Unpublished Report. Ministry of Water Resources, Bauchi State Water Board and Sewerage Cooperation, Bauchi.

Healy, A.; K. Upton, S. Capstick, G. Bristow, M. Tijani, A. Macdonald, I. Goni, Y. Bukar, L. Whitmarsh, S. Theis, K. Danert and S. Allan (2020). Domestic Groundwater Abstraction in Lagos, Nigeria: A Disjuncture in the SciencePolicy-Practice Interface? Environ. Res. Lett. 15 (4):1-13.

Hicks, F.E. and Peacock, T. (2005). Suitability of HECRAS for Flood Forecasting. Canadian Water Resour. J. 30 (2): 159-174.

Husain, A.; M. Sharif, and M.L. Ahmad (2018). Simulation of Floods in Delhi Segment of River Yamuna Using HEC-RAS. Am. J. Water Resour. 4 (4):164-168.

Japan International Cooperation Agency (JICA) (2014). National Water Resources Master Plan 2013. Federal Ministry of Water Resources, Volume 4, Abuja. Federal Government of Nigeria.

Johnson, B.E.; M. George, and Z. Zhang, (2018). The Demonstration and Validation of a Linked Watershed Riverine Modeling System for DOD Installations-Calleguas, California. Worshington DC: US Corps of Engineers.

Kabiri, R., Chan, A. and Bai, R. (2013). Comparison of SCS and Green-Ampt Methods in Surface Runoff-Flooding Simulation for Klang Watershed in Malaysia. Open J. Modern Hydrol. 03(03): 102-114.

Kumar, D.N. and Tv, R. (2013). Remote Sensing Applications in Water Resources. J Indian Inst Sci. 93(2): 163184.

Kuria, F.W. and Vogel, R.M. (2014). A Global Water Supply Reservoir Yield Model with Uncertainty Analysis. Environ. Res. Lett. 9 (9): 1-7.

Lang, M.; M. Al-Zahrani, A. Al-Areeq, H. Sharif, F. Klijn, and P. Samuels (2016). Flood Analysis using HECRAS Model: A Case Study for Hafr Al-Batin, Saudi Arabia. E3S Web of Conferences, 1-5. 
Liu, J.; C. Zhang, L. Kou, and Q. Zhou (2017). Effects of Climate and Land Use Changes on Water Resources in the Taoer River. Adv Meteorol. 2017: 1-13.

McCorquodale, A.; I. Georgiou, M. Davis and J. Pereira (2010). Hydrology and Hydrodynamic Modeling of the Mississippi River in Southeast Louisiana. New Orleans: University of New Orleans.

McCuen, R.H. (1989). Hydrologic Analysis and Design $2^{\text {nd }}$ ed. New Jersey, Prentice - Hall Inc.

Mondal, M.S., Islam, A.K.M.S., Haque, A., Islam, M.R., Biswas, S. and Mohammed, K. (2018). Assessing High-End Climate Change Impacts on Floods in Major Rivers of Bangladesh using Multi-Model Simulations. Global Sci Technol. 6 (2): 1-14.

Nyaupane, N.; B. Thakur, A. Kalra and S. Ahmad (2018). Evaluating Future Flood Scenarios using CMIP5 Climate Projections. Water. 10 (12): 1-18.

Oyegoke O.O.; A. S. Adebanjo and H. J. Ododo (2020). Rainfall Intensity Analysis for Synoptic Stations in Northern Nigeria. Nigerian Journal of Technological Development. 17(3): 223-228.

Parhi, P.K. (2018). Flood Management in Mahanadi Basin using HEC-RAS and Gumbel's Extreme value Distribution. J. Inst. Eng. India Ser. A. 99 (4): 751-755.

Salaudeen, A.; A. Ismail, B. K. Adeogun, M. A. Ajibike and S. Shahid (2021). Assessing the Skills of Inter-Sectoral Impact Model Intercomparison Project Climate Models for Precipitation Simulation in Gongola Basin of Nigeria. Scientific African. 13 (2021): 1-13.

Salau, O.B.E. and Salaudeen, A. (2017). Technical
Analysis of Hydrologic Issues for Dadin Kowa Dam Safety Evaluation. Int J Sci Technol Res. 6 (11): 58-62.

Salaudeen, A.; S. Shahid, T. Ismail, E.-S. Chung, M. Mohsenipour and X.-J. Wang (2016). Prediction of Flow Duration Curve in Ungauged Catchments using Gene Expression Programming. Procedia Eng. 154: 1431-1438.

Schneider, L.E. and McCuen, R.H. (2005). Statistical Guidelines for Curve Number Generation. J. Irrig. Drain. Eng. 13: 282-290.

Shrestha, S. and Lohpaisankrit, W. (2017). Flood Hazard Assessment under Climate Change Scenarios in the Yang River Basin, Thailand. International Journal of Sustainable Built Environment. 6 (2): 285-298.

Silva, G.D.; S.B. Weerakoonb and S. Herath (2016). Event Based Flood Inundation Mapping Under the Impact of Climate Change: A Case Study in Lower Kelani River Basin, Sri Lanka. Hydrol Current Res. 7 (1):1-4.

Soulis, K.X. and Valiantzas, J.D. (2012). SCS-CN Parameter Determination using Rainfall-Runoff Data in Heterogeneous Watersheds and the Two-CN System Approach. Hydrol. Earth Syst. Sci. 16 (3):1001-1015.

United State Department of Agriculture (1986). Urban Hydrology for Small Watersheds. Second ed. Washington, DC.

United States Bureau of Reclamation (1987). Design of Small Dams. Princeton, New Jersey.

Uwizeyimana, D.; S.M. Mureithi, S.M. Mvuyekure, G. Karuku and G. Kironchi (2019). Modelling Surface Runoff using the Soil Conservation Service-Curve Number Method in a Drought Prone Agro-Ecological Zone in Rwanda. Int. Soil Water Conserv. Res. 7 (1): 9-17. 